


\section{The European Union Strategy for the Baltic Sea Region and the Level of Competitiveness of the BSR Economies}

Keywords: Baltic Sea Region, European Union for the Baltic Sea Region, 2007-2013, competitiveness Słowa kluczowe: region Morza Bałtyckiego, Strategia UE dla regionu Morza Bałtyckiego, 2007-2013, konkurencyjność

\section{Introduction}

Although the Baltic Sea Region is regarded as the European Union periphery, it is the region of the best macroeconomic indicators and a high position with regard to its competitiveness. It was the first region included in the EU macro regional strategy, due to huge disparities between the level of development in the countries of the Northern and Southern Baltic and the increasing degradation of sea waters. The aim of the paper is to examine how the European Union Strategy for the Baltic Sea Region 2007-2013 affected the competitiveness of the economies in this region in a macroeconomic context.

\section{Disparities in the economies of the Baltic Sea Region}

The Baltic Sea Region includes the economies which are highly diversified with regard to their resources, size, membership in organisations, and monetary systems (Table 1). The similar natural conditions have not influenced the social-economic development of these countries as much as their history and politics, the consequences of which find reflection in the level of competitiveness of particular economies. ${ }^{1}$

\footnotetext{
* Dr Katarzyna Skrzeszewska, Akademia Morskaw Gdyni, e-mail: k.skrzeszewska@wpit.am.gdynia.pl.

1 K. Skrzeszewska, Konkurencyjność krajów Regionu Morza Battyckiego w świetle międzynarodowych rankingów, Prace Naukowe UE we Wrocławiu - Ekonomia, eds. M. Rękas, J. Sokołowski, Wyd. UE we Wrocławiu, Wrocław 2013.
} 
Table 1. Membership of the BSR countries in selected international organisations

\begin{tabular}{|c|c|c|c|c|c|}
\hline \multirow[b]{2}{*}{ Country } & \multirow[b]{2}{*}{ European Union } & \multicolumn{3}{|c|}{ Eurozone } & \multirow[b]{2}{*}{ NATO } \\
\hline & & in the zone & $\begin{array}{l}\text { with a Euro } \\
\text { derogation }\end{array}$ & before the access & \\
\hline Denmark & $+1973^{*}$ & & + & & $+(1949)$ \\
\hline Germany & $+(1952)$ & $+(2002)$ & & & $+(1955)$ \\
\hline Poland & $+(2004)$ & & & + & $+(1999)$ \\
\hline Russia & - & - & - & - & - \\
\hline Lithuania & $+(2004)$ & & & + & $+(2004)$ \\
\hline Latvia & $+(2004)$ & $+(2014)$ & & & $+(2004)$ \\
\hline Estonia & $+(2004)$ & $+(2011)$ & & & $+(2004)$ \\
\hline Finland & $+(1995)$ & $+(2002)$ & & & - \\
\hline Sweden & $+(1995)$ & & & + & - \\
\hline
\end{tabular}

* the access year

Source: the author's own elaboration.

Eight out of ten countries of the BSR belong to the European Union, half of which are also in the Eurozone. ${ }^{2}$ Apart from Denmark, which is the member state with Euro derogation, other countries are obliged to introduce the common currency. Apart from the economic bonds, some countries cooperate also within the framework of a military alliance. The country which does not belong to any of the above mentioned organisations or structures is Russia.

As far as the number of citizens is concerned, the countries in the Baltic Sea Region can be divided, according to the criteria adopted for the needs of this paper, into:

- small countries, below 5 million citizens (Lithuania, Lithuania, Estonia),

- medium countries, from 5 to 10 million citizens (Denmark, Finland, Sweden),

- big countries, more than 10 million citizens (Germany, Poland, Russia) (Figure 1).

While analysing the changes in the number of citizens in the particular countries over the last 15 years, it can be stated that the population growth has occurred only in the medium-sized countries (Denmark, Finland by $6 \%$, Sweden by $9 \%$ ). In the big countries, the situation is quite stabile and the changes, which can be noticed in particular years, do not have any significant meaning with regard to the whole analysed period. A considerable fall in the population size has been noticed in the smaller countries: in Estonia by $5 \%$, and in Lithuania and Latvia by as much as $17 \%$.

2 Since 1 January 2015, Lithuania has become the fifth country in the BSR, and as the nineteenth in the EU has entered the Eurozone. 
Figure 1. The number of citizens in particular BSR countries (small, medium, big)
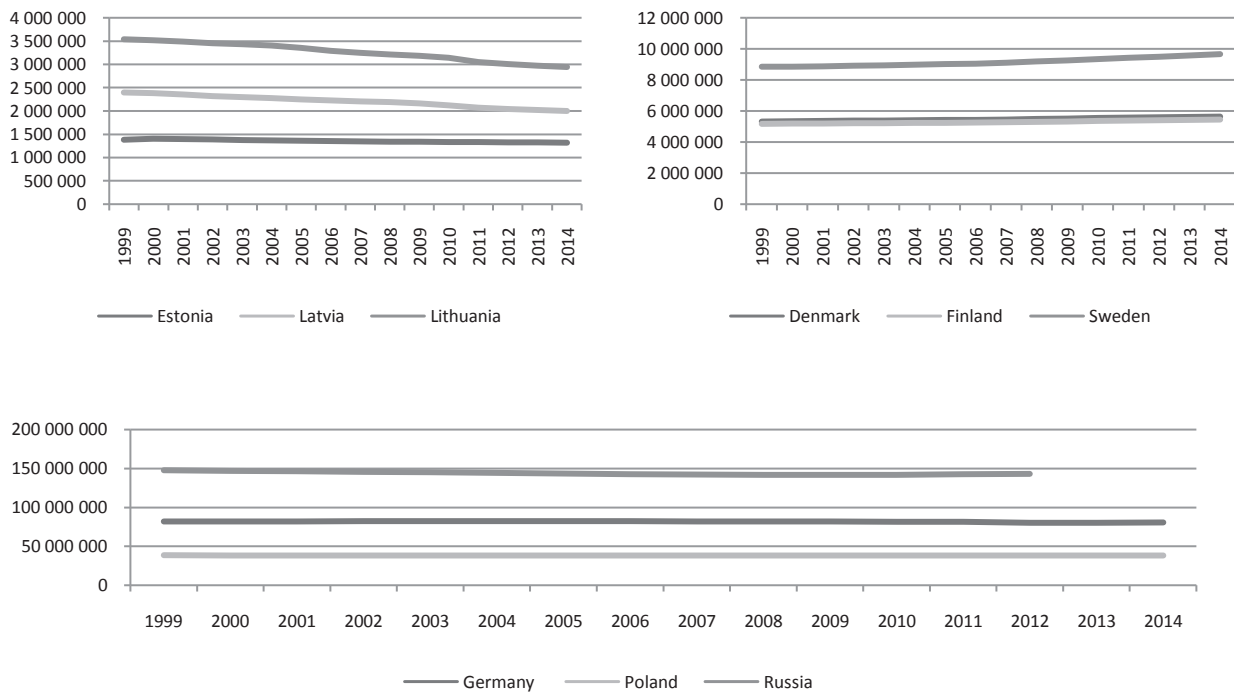

Source: author's own study based on Eurostat data.

Economic diversity of the BSR countries is significant. With regard to the disparities in the population size mentioned above, the economies should be compared on the basis of the indicators calculated per capita. For brevity, only one indicator was chosen to show the differences in the level of the development of the economies, i.e. Gross Domestic Product calculated per capita (Table 2).

Table 2. The value of GDP per capita expressed in USD, current prices*

\begin{tabular}{|l|c|c|c|c|c|c|c|c|c|c|}
\hline \multicolumn{1}{|c|}{ Country } & 2004 & 2005 & 2006 & 2007 & 2008 & 2009 & 2010 & 2011 & 2012 & 2013 \\
\hline Denmark & 45,282 & 47,547 & 50,462 & 57,021 & 62,596 & 56,227 & 56,411 & 59,912 & 56,364 & 58,894 \\
\hline Germany & 33,040 & 33,543 & 35,238 & 40,403 & 44,132 & 40,270 & 40,408 & 44,355 & 42,598 & 45,085 \\
\hline Finland & 36,163 & 37,319 & 39,487 & 46,538 & 51,187 & 44,838 & 44,134 & 48,695 & 45,649 & 47,219 \\
\hline Sweden & 40,261 & 41,041 & 43,949 & 50,558 & 52,731 & 43,640 & 49,377 & 56,724 & 55,039 & 58,269 \\
\hline Poland & 6,620 & 7,963 & 8,958 & 11,157 & 13,886 & 11,295 & 12,304 & 13,385 & 12,721 & 13,432 \\
\hline Lithuania & 6,710 & 7,851 & 9,250 & 12,170 & 14,833 & 11,714 & 11,852 & 14,228 & 14,172 & 15,538 \\
\hline Latvia & 6,081 & 7,165 & 8,986 & 13,073 & 15,464 & 12,082 & 11,447 & 13,827 & 13,947 & 15,375 \\
\hline Estonia & 8,830 & 10,264 & 12,473 & 16,405 & 17,786 & 14,542 & 14,295 & 16,982 & 16,887 & 18,478 \\
\hline Russia & 4,109 & 5,338 & 6,948 & 9,145 & 11,700 & 8,616 & 10,710 & 13,324 & 14,091 & 14,612 \\
\hline $\begin{array}{l}\text { The world } \\
\text { (on average) }\end{array}$ & 10,196 & 11,044 & 12,032 & 13,792 & 14,507 & 12,302 & 11,994 & 13,314 & 12,378 & 11,729 \\
\hline
\end{tabular}

* shaded GDP per capita exceeding the world's average value in a given year

Source: World Bank, http://data.worldbank.org/ (10.12.2014). 
In 2004, the disparities between the richest countries of the North-Western Baltic and the other countries, calculated with GDP per capita exceeded 1000\%. Additionally, only Scandinavians and Germans had higher (many times) GDP per capita in comparison to the world's average. Clear differences occurred in 2008, when the Baltic countries joined the countries with higher than average GDP per capita. Yet, in the next year, the effects of the world crisis negatively influenced the results of all the BSR countries, particularly the weakest countries, where the decreases reached about $20 \%$, whereas in relation to the rich countries, the changes were more or less twice lower. Since2010, the whole Region has obtained GDP per capita higher than the world's average. The disparities have definitely changed: the highest value of this indicator (Denmark) exceeds the weakest (Poland) only four times.

\section{The objectives and scope of the European Union Strategy for the Baltic Sea Region}

The Baltic is the focus of interest of many organisations, and it inspires many initiatives on different levels of authorities and in different thematic areas. Their aims can be all comprised in the common subject matter, i.e. to focus on the sustainable development in the BSR. The cooperation in this region is well developed. The common activities undertaken within the organisation framework on different levels became intensified in the 1990s. The most significant initiatives and organisations, from the point of view of the scope and the rank of the undertaken activities, are:

- The Baltic Marine Environment Protection Commission (Helsinki Commission, HELCOM, 1974),

- The Nordic Council (1952),

- The Baltic Assembly (1990),

- Union of the Baltic Cities (1991),

- The Council of the Baltic Sea States (1992),

- The Northern Dimension of the EU (1997, a joint policy of the UE member states, Island, Norway and Russia, the aim of which is to promote the activities facilitating the cooperation and the sustainable development of the Northern Europe), ${ }^{3}$

- Baltic Development Forum (1998, the network of more than 8000 top level decision making entities of the world of business, politics, science and media), ${ }^{4}$

\footnotetext{
3 Northern Dimension Partnership in Public Health and Social Prosperity, http://www.ndphs. org/?language,Polski,about_nd (11.12.2014).

4 Baltic Development Forum, http://www.bdforum.org/baltic-development-forum-introduction/ (14.12.2014).
} 
- Common areas EU -Russia (2003, 4 common areas of mutual cooperation: 1) economic, 2) freedom, security, and justice, 3) national security, 4) scientific research, education, and culture),

- EU Common Policies (among others: cohesion policy, environment policy, and integrated maritime policy),

- Baltic Metropoles Network (common activities promoting the innovativeness and competitiveness of the BSR). ${ }^{5}$

The majority of the initiatives were undertaken just after the dissolution of the Eastern Bloc and the political-economic transformations of people's democracy in the former countries. Despite so many organisations, the cooperation of which is shaped on the governmental, parliamentary, and local scale, the development of the Baltic Sea Region countries was not satisfactory. The European Commission stated that in spite of "the effective cooperation on the international and interregional level, new opportunities resulting from EU membership have not yet been fully exploited and no one has found the proper solution to problems the whole region has been facing." ${ }^{16}$ The initiative to develop the strategy for the BSR was undertaken by the European Parliament in November 2006, when they adopted the resolution postulating the elaboration of such a document. The BSR strategy was announced in the Communication of the Commission in June 2009 and approved of by the European Council in October the same year. It included eight Union countries with an access to the Baltic Sea, and in some justified cases its range of activities could be expanded by the participation of Norway, Russia, and Belarus. The realisation of the strategy was to be based on the existing institutional structures and regulations. No extra resources were allocated for its implementation in the EU budget. The strategy was based on four pillars (ecology, prosperity, accessibility and attractiveness of the region, safety and security), which reflect a wide range of political activities, and are complementary to one another, so that an activity in one of them will affect the other pillars.

The implementation of the Strategy was carried out by implementing the Action Plan, which contained Priority Areas (17), and by Horizontal Actions (5). ${ }^{8}$ Within these projects, the Flagship Projects were implemented (Table 3).

\footnotetext{
5 The Baltic Metropoles Network, http://www.baltmet.org/titlepage (14.12.2014).

6 Komunikat Komisji do Parlamentu Europejskiego, Rady, Europejskiego Komitetu Ekonomiczno-Społecznego i Komitetu Regionów dotyczacy Strategii Unii Europejskiej dla regionu Morza Bałtyckiego, KOM (2009) no. 248, Bruksela 10.09.2009.

7 Ibidem.

8 Plan Działania, dokument roboczy Stużb Komisji uzupetniajacy Komunikat Komisji do Parlamentu Europejskiego, Rady, Europejskiego Komitetu Ekonomiczno-Społecznego i Komitetu Regionów dotyczący Strategii Unii Europejskiej dla regionu Morza Bałtyckiego, SEC (2009) 712/2, Bruksela, 19.06.2009.
} 
Table 3. Priority issues outlined within partial and overall objectives of the EU Strategy for the BSR

\begin{tabular}{|c|c|c|}
\hline Objectives & Partial objectives & Priority issues \\
\hline \multirow{7}{*}{ Save the sea } & clean waters in the sea & $\begin{array}{l}\text { biogenic substances - reducing the inputs of biogenic } \\
\text { substances to the Baltic Sea }\end{array}$ \\
\hline & \multirow{3}{*}{ rich and healthy wild fauna and flora } & $\begin{array}{l}\text { agriculture - reinforcing sustainability of agriculture, forestry } \\
\text { and fishery }\end{array}$ \\
\hline & & biological diversity - preserving biodiversity in the BSR \\
\hline & & $\begin{array}{l}\text { threats - reducing the use and the impact of substances } \\
\text { hazardous to the environment }\end{array}$ \\
\hline & \multirow[t]{2}{*}{ ecological and safe transport } & $\begin{array}{l}\text { safety } \\
- \text { increasing the level of safety and security of life on the sea }\end{array}$ \\
\hline & & shipping - creating conditions for ecological shipping in the BSR \\
\hline & improvement of cooperation & $\begin{array}{l}\text { security - protection from emergencies and accidents } \\
\text { on the land }\end{array}$ \\
\hline \multirow{4}{*}{$\begin{array}{l}\text { Connecting } \\
\text { the region }\end{array}$} & good transport conditions & $\begin{array}{l}\text { transport - more convenient transport links inside and outside } \\
\text { the BSR }\end{array}$ \\
\hline & reliable sources of energy & $\begin{array}{l}\text { energy - improving the access to, and the efficiency } \\
\text { and security of the energy markets }\end{array}$ \\
\hline & connecting people in the region & - \\
\hline & $\begin{array}{l}\text { improvement of cooperation in fighting } \\
\text { cross-border trade crime }\end{array}$ & crime - fighting cross-border crime \\
\hline \multirow{8}{*}{$\begin{array}{l}\text { Increasing } \\
\text { prosperity }\end{array}$} & $\begin{array}{l}\text { EUSBRS (the European Union Strategy } \\
\text { for the Baltic Sea Region) as an } \\
\text { important instrument in developing } \\
\text { and realizing the cohesive market }\end{array}$ & $\begin{array}{l}\text { internal market - removing hindrances to the operation } \\
\text { of the internal market }\end{array}$ \\
\hline & \multirow{2}{*}{$\begin{array}{l}\text { EUSBSR } \\
\text { in the implementation of the strategy } \\
\text { 'Europe 2020' }\end{array}$} & health - improving and promoting health \\
\hline & & $\begin{array}{l}\text { innovations - exploiting the potential of the region in R\&D } \\
\text { activities }\end{array}$ \\
\hline & \multirow{4}{*}{$\begin{array}{l}\text { improvement of competitiveness } \\
\text { of the BSR on the global market }\end{array}$} & $\begin{array}{l}\text { culture - developing and promoting the common culture } \\
\text { and cultural identity }\end{array}$ \\
\hline & & education - developing innovative teaching methods \\
\hline & & $\begin{array}{l}\text { SMEs - implementing "Magna carta of small enterprises": } \\
\text { promoting } \\
\text { entrepreneurship, increasing the significance of the sector }\end{array}$ \\
\hline & & tourism - raising awareness of the BSR cohesion \\
\hline & $\begin{array}{l}\text { adaptation to the climate change, risk } \\
\text { prevention and risk management }\end{array}$ & - \\
\hline
\end{tabular}

Source: KOM(2009) 248, SEC(2009) 712/2.

The realisation of the objectives outlined in the Strategy was to bring about the changes which would result in the BSR achieving the status of:

- the region ecologically sustainable,

- the region of prosperity,

- the accessible and attractive region,

- the safe region. ${ }^{9}$

$9 \quad$ Komunikat Komisji... 
Apart from the activities undertaken in the selected priority areas, the European Commission pointed out the necessity of undertaking horizontal actions (HA). These were:

- HA 'Involve' - strengthening multilevel governance,

- HA 'Neighbours' - increasing the cooperation with neighbouring countries,

- HA 'Promo' - intensifying common promotional activities and the activities designed to build regional identity,

- HA 'Spatial' - encouraging the use of spatial planning in maritime and land areas,

- HA 'Sustainable' - sustainable development and bio-economy, the objective of which is to transform the BSR into the region of prosperity. ${ }^{10}$

The implementation of the strategy was possible thanks to the program resources coming from the Union funds and others. The total sum allocated for this aim, which was accessible at the beginning of the program, was EUR 222.8 million. These funds came from:

- the European Regional Development: EUR 208 million,

- the European Neighbourhood and Partnership Instrument: EUR 8.8 million,

- the Norwegian National Funding: EUR 6 million,

- the funds allocated together with partners to finance the projects. ${ }^{11}$

The programmes realised within the EUSBSR were financed to a different extent, depending on the country of origin of the partner: $75 \%$ costs qualified in case of Denmark, Germany, Sweden and Finland; 85\% for Estonia, Lithuania, Latvia and Poland; $50 \%$ for Norway; $90 \%$ for Belarus. ${ }^{12}$

In five competitions, all together 90 projects were approved, including 75 with Polish partners. The majority of the approved projects, namely 28 , were included in the priority 'innovations development', including 26 with Polish participation. The next, with regard to the number, were: 'Attractiveness and competitiveness of cities and regions' 23 projects including 13 with Polish participation; 'The Baltic Sea' as a common resource -21 (total) and 17 (with Polish participation); 'External and internal accessibility' 18 and 13 (respectively). ${ }^{13}$

167 partners from Poland participated in the implementation of the Strategy. The majority of them were from the following voivodeships: Pomeranian (60), Masovian (24), West Pomeranian (20) and Greater Poland (14). In the other voivodeships, the interest in the programme was considerably lower (3-8 partners), and Świętokrzyskie Voivode-

10 Ibidem.

11 Program wspólpracy transnarodowej Regionu Morza Bałtyckiego. Podsumowanie realizacji programu 2007-2013, Ministerstwo Infrastruktury i Rozwoju, Warszawa 2014.

12 Baltic Sea Region Programme 2007-2013.

13 Program wspótpracy transnarodowej... 
ship did not participate in it at all. In comparison to the other states of the BSR, the Polish participation was noticeable. With regard to the number of partners, Poland took the fourth position, behind Sweden (about 230 partners), Germany (about 230 partners), and Finland (about180 partners). In the other countries of the BSR, the number of partners oscillated around 150 (Lithuania), 110 (Latvia, Estonia), and 105 (Denmark).

With regard to finances, disparities were clearly noticeable both on the local (Figure 2) and regional scale.

Figure 2. The level of financing the Polish partners, in particular voivodeships (in thousands of EUR)

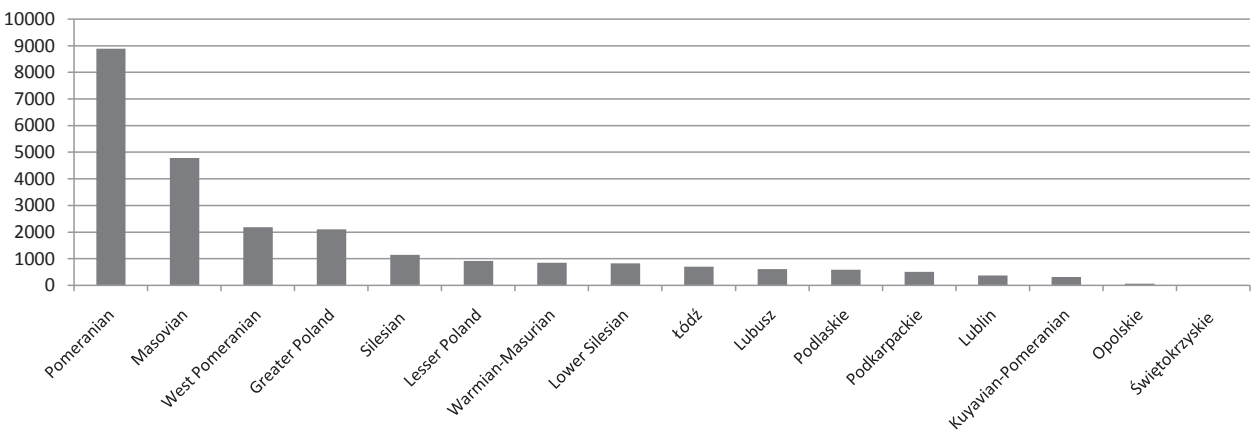

Source: author based on: Program współpracy transnarodowej...

The Polish partners who obtained financing on the level of EUR 25 million came in fourth behind: the Swedish (about EUR 42 million), the Germans (about EUR 40.5 million), the Finnish (about EUR 31 million). Lower financing was allocated to: the Lithuanian (about EUR 19 million), the Danish (EUR 18 million), the Latvian (about EUR 14 million) and the Estonian (about EUR 13 million). ${ }^{14}$

\section{Evaluation of the changes in the level of competitiveness of the economies of the BSR}

International competitiveness of a country is a relatively new area of research. In the mid 1980s, when Asian economies started to grow on an unparalleled scale, in different places all over the world, new institutions were set to examine the competitiveness of economies. Among them, apart from higher education institutions, there are scientific and research institutes (e.g. The International Institute for Management Development-

14 Program wspótpracy transnarodowej... 
IMD), international organisations (e.g. The World Economic Forum - WEF), as well as institutions and private enterprises (e.g. The Heritage Foundation). ${ }^{15}$

Competitiveness is defined on the basis of different criteria. It has been estimated that the number of definitions of competitiveness is up to $400 .{ }^{16}$ Following the aim, as stated in the introduction of this paper, the indicators describing the competitiveness of the national economy should cover also the issues connected with the real economy and the regulatory sphere. Both aspects are included in the indicators of competitiveness of IMD and WEF. The analysis of the changes in the position of competitive economies in the BSR will be conducted on the basis of the IMD indicator, ${ }^{17}$ formulated on the basis of about 300 criteria. $^{18}$ The criteria are divided into four groups: economic conditions, effectiveness of the government, effectiveness of enterprises, and infrastructure. The number of the factors in each of the four groups shows that the aspects of the highest significance are these which affect the dynamics of the economy development. ${ }^{19}$

Table 4. Ranking of competitiveness of the Baltic Sea Region countries, according to IMD, in the years 2004-2014

\begin{tabular}{|l|r|r|r|r|r|r|r|r|r|r|r|}
\hline & 2004 & 2005 & 2006 & 2007 & 2008 & $2009^{* *}$ & 2010 & 2011 & 2012 & 2013 & 2014 \\
\hline Sweden & 11 & 14 & 14 & 9 & 9 & 6 & 6 & 4 & 5 & 4 & 5 \\
\hline Germany & 21 & 23 & 26 & 16 & 16 & 13 & 16 & 10 & 9 & 9 & 6 \\
\hline Denmark & 7 & 7 & 5 & 5 & 6 & 5 & 13 & 12 & 13 & 12 & 9 \\
\hline Finland & 8 & 6 & 10 & 17 & 15 & 9 & 19 & 15 & 17 & 20 & 18 \\
\hline Estonia & 28 & 26 & 20 & 22 & 23 & 35 & 34 & 33 & 31 & 36 & 30 \\
\hline Poland & 57 & 57 & 58 & 52 & 44 & 44 & 32 & 34 & 34 & 33 & 36 \\
\hline Lithuania & - & - & - & 31 & 36 & 31 & 43 & 45 & 36 & 31 & 34 \\
\hline Latvia & - & - & - & - & - & - & - & - & 41 & 31 & 34 \\
\hline Russia & 50 & 54 & 54 & 43 & 47 & 49 & 51 & 49 & 48 & 42 & 38 \\
\hline
\end{tabular}

"Shaded cells: the country's position in the first twenty countries of the highest competitiveness (light gray), in the second twenty (darker tone of gray), the third twenty - no background.

"The distinguished (bold line) period corresponds to the period in which the activities within the EU Strategy for the BSR were undertaken.

Source: World Competitiveness Report, IMD, Geneva 2004-2014, http:/www.imd.org/research/publications/wcy/upload/scoreboard.pdf.

15 K. Skrzeszewska, Konkurencyjność...

16 Konkurencyjność Polski na tle zmian gospodarczych w krajach OECD. Ewolucja znaczenia czynników konkurencyjności, eds. W. Bieńkowski, M. A. Weresa, M. J. Radło, Oficyna Wydawnicza SGH, Warszawa 2010.

17 IMD indicator was chosen because of the wide scope of the criteria which are used to construct it. Thanks to the drivers of the productivity and prosperity this indicator assesses the present national competitiveness and the possibilities of the potential growth.

18 The number of the criteria is not constant. It changes along with the changes in the method of assessing the competitiveness indicator.

19 World Competitiveness Report, IMD, Geneva 2004-2014. 
Table 4 compares the positions of the BSR countries in the IMD ranking of competitiveness. It turns out that the division into the most competitive economies on the world's scale and the others has remained the same over the last few years, irrespectively of the regional initiatives undertaken in the basin of the Baltic Sea, the Union, or international initiatives. In the first twenty most competitive economies, there are the richest countries, which, with regard to the factors determining the dynamics of the economy development, definitely exceed the countries of the South-East Baltic. Analysing the positions of the smallest countries in the ranking of competitiveness, it can be concluded that their situation depends more on the world's economic circumstances than on the programmes for the sustainable development of the Region. It is clearly visible when the period in which the programme is operating, is compared to the earlier period. The world crisis caused that the competitiveness position of these economies decreased during the implementation of the Strategy of the BSR. Nevertheless, the level of the competitiveness of the whole Region over the last 11 years has improved. In 2004, when the EU was accessed by, among others, the Baltic countries and Poland, in this region there were only two states from the first ten and two from the second ten of the most competitive economies of the world. The other states either were not classified or had the position in the other half of the first hundred. Nowadays, three states are in the first ten, and the others take the position in the first forty. On the basis of these facts, it can be stated that over the last few years the Region has gained significance not only on the European scale.

\section{Conclusion}

The Baltic Sea Region is an important area for the European Union in spite of its peripheral location. The potential of the region is shown, among others, by high GDP per capita, in case of some economies exceeding many times the world's average value. However, the positive aspects are assisted by negative ones: big disparities in the development level of particular economies, high level of the pollution of the Baltic and its consequences. As a result, the sustainable development and environment protection are the objectives of many Baltic organisations. Such an objective was also set by the European Commission and announced in 2009 in the EUSBSR for the years 2007-2013. The Strategy comprised the areas not only from the EU, but the whole basin of the Baltic. Poland actively participated in the implementation of the Strategy:

- Polish partners took part in 75 projects (out of 90),

- the most active voivodeships were: Pomeranian, Masovian, West Pomeranian, and Greater Poland,

- 167 Polish partners were engaged in the implementation of the projects; these were, first of all, scientific and research institutes, Marshal's offices, and higher education institutions, 
- Polish partners obtained financing of EUR 25 million for the implementation of the projects.

The biggest beneficiaries of the projects implemented within the Strategy for the BSR were the richest countries: Sweden, Germany, and Finland.

Literature

Baltic Development Forum, www.bdforum.org/baltic-development-forum-introduction (14.12.2014).

Baltic Sea Region. Programme 2007-2013,http://eu.baltic.net/Funding.113.html (15.12.2014).

Konkurencyjność Polski na tle zmian gospodarczych w krajach OECD. Ewolucja znaczenia czynników konkurencyjności, eds. W. Bieńkowski, M.A. Weresa, M.J. Radło, Oficyna Wydawnicza SGH, Warszawa 2010.

Eurostat, http://ec.Europa.eu/Eurostat/web/main (9.12.2014).

Komunikat Komisji do Parlamentu Europejskiego, Rady, Europejskiego Komitetu Ekonomiczno-Społecznego i Komitetu Regionów dotyczacy Strategii Unii Europejskiej dla regionu Morza Battyckiego, KOM (2009) no. 248, Bruksela 10.09.2009.

Northern Dimension Partnership in Public Health and Social Well-being, www.ndphs. org/?language,Polski,about_nd (11.12.2014).

Program wspótpracy transnarodowej Regionu Morza Bałtyckiego. Podsumowanie realizacji programu 2007-2013, Ministerstwo Infrastruktury i Rozwoju, Warszawa 2014.

Plan Działania, dokument roboczy Stużb Komisji uzupetniajacy Komunikat Komisji do Parlamentu Europejskiego, Rady, Europejskiego Komitetu Ekonomiczno-Społecznego i Komitetu Regionów dotyczący Strategii Unii Europejskiej dla regionu Morza Bałtyckiego, SEC (2009) 712/2, Bruksela, 19.06.2009.

Skrzeszewska K., Konkurencyjność krajów Regionu Morza Battyckiego w świetle międzynarodowych rankingów, Prace Naukowe UE we Wrocławiu - Ekonomia, eds. M. Rękas, J. Sokołowski, Wyd. UE we Wrocławiu, Wrocław 2013.

The Baltic Metropoles Network, www.baltmet.org/titlepage (14.12.2014).

World Bank, http://data.worldbank.org/ (10.12.2014).

World Competitiveness Report, IMD, Geneva 2004-2014.

\section{Abstract}

Huge economic disparities between the BSR countries can adversely affect the development of the region in the economic and social aspect, and also the level of environmental protection. The initiatives for the cooperation undertaken over the years have resulted in a number of Baltic organisations being involved in the sustainable development of the region. The initiative, which was to accelerate the convergence of the weaker countries and to make the region prosperous, attractive, and safe, was the EU Strategy for the BSR, 2007-2013. It is impossible to separate the Strategy effects from the effects of the implementation of the EU policies, and the activities undertaken by many Baltic organisations. It should be noted, however, that the positive effects of this cooperation can be seen, for example in the rankings of competitiveness among the Baltic economies. 


\section{Strategia Unii Europejskiej dla regionu Morza Bałtyckiego oraz poziomu konkurencyjności gospodarek BSR}

Ogromne różnice gospodarcze pomiędzy krajami regionu Morza Bałtyckiego mogą niekorzystnie wpływać na rozwój regionu w aspekcie ekonomicznym i społecznym, a także na poziom ochrony środowiska. Podejmowane w ostatnich latach inicjatywy na rzecz współpracy doprowadziły do powstania wielu organizacji bałtyckich zaangażowanych w zrównoważony rozwój regionu. Inicjatywą mającą na celu przyspieszenie konwergencji słabszych krajów, w celu uczynienia regionu zamożniejszym, atrakcyjnym i bezpiecznym, była Strategia UE dla regionu Morza Bałtyckiego 2007-2013. Niemożliwe jest oddzielenie efektów Strategii od realizacji polityki UE oraz działań podejmowanych przez wiele organizacji bałtyckich. Należy jednak zauważyć, że pozytywne efekty tej współpracy można dostrzec na przykład w rankingach konkurencyjności między gospodarkami bałtyckimi. 